\title{
Удосконалення методики фізичної підготовки курсантів ЗВО МВС України зі специфічними умовами навчання
}

\section{Андрій Забора Олег Камаєв}

Харківська державна академія фізичної культури, Харків, Україна

\begin{abstract}
Мета: розробити та експериментально обгрунтувати вдосконалену методику фізичної підготовки курсантів.
Матеріал і методи: дослідження виконано на навчально-спортивній базі Харківського національного університету внутрішніх справ (ХНУВС). У дослідженні брали участь 46 курсантів двох академічних груп другого року навчання. Було створено експериментальну $(n-24)$ i контрольну $(n-22)$ групи. Експеримент тривав протягом четвертого семестру. У роботі використано наступні методи дослідження: аналіз та узагальнення науково-методичної інформації, педагогічне спостереження, тестування, педагогічний експеримент, методи математичної статистики.

Результати: за рахунок використання експериментальної методики, підбору засобів та методики виконання комплексних вправ одержано приріст показників фізичної та спеціальної підготовленості курсантів.
\end{abstract}

Висновки: розроблена методика удосконалення фізичної підготовки забезпечила достовірне покращення показників фізичної підготовленості курсантів і сприяє успішному оволодінню вправами тактики самозахисту.

Ключові слова: курсанти, фізична підготовка, тестування, фізичні якості, кросфіт.

\section{Вступ}

На сучасному етапі розвитку та становлення незалежності української держави процес соціальних, політичних, економічних перетворень спрямовано на демократизацію й реформування всіх сфер громадянського суспільства: науки, освіти, охорони здоров'я, армії, поліції відповідно до Європейського та світових стандартів. Але у зв'язку зі складними соціально-економічними та морально-політичними умовами розбудова незалежної української державності супроводжується високим рівнем криміногенної ситуації, що негативно впливає на стан законності та правопорядку в країні [2; 6; 7].

У таких умовах суспільство і держава чітко визначають завдання перед працівниками Національної поліції України. Так, у нормативних документах, зокрема у Законі України «Про Національну поліцію» (2015), регламентовано та конкретизовано, що поліція під час виконання повноважень, визначених цим Законом, уповноважена застосовувати такі заходи примусу: фізичний вплив (сила); застосування спеціальних засобів; застосування вогнепальної зброї [8].

У зв'язку з цим на сучасному етапі розвитку професійної освіти у підготовці фахівців Національної поліції особливе місце займає проблема формування належного рівня фізичної підготовленості. Але доцільність розв'язання зазначеної проблеми пов'язана з необхідністю подолання протиріч між сучасними вимогами, що задекларовано в нормативно-законодавчих документах MBC України щодо сформованості фізичної підготовленості та реально існуючим рівнем загально-фізичної підготовленості курсантів, між об'єктивною потребою формування належного рівня фізичної підготовленості та рівнем загально-фізичної підготовленості абітурієнтів, які вступають у заклади вищої освіти МBC; між суттєво значним існуючим потенціалом комплексного формування достатнього рівня фізичної підготовленості та ефективного поєднання з іншими напрямами фахової підготовки, зокрема тактичної, вогневої, психологічної; між необхідністю ефективним володінням прийомами самозахисту та рухово-координаційними можливостями курсантів [1; 3; 4; 5].

У зв'язку з цим пошук найбільш ефективних засобів і методів фізичної підготовки в межах існуючих нормативно-законодавчих вимог набуває особливої актуальності.

Мета дослідження: розробити та експериментально обґрунтувати вдосконалену методику фізичної підготовки курсантів ХНУВС.

\section{Матеріал і методи дослідження}

Методи дослідження: аналіз та узагальнення науково-методичної інформації, педагогічне спостереження, тестування, педагогічний експеримент, методи математичної статистики.

Дослідження виконано на навчально-спортивні базі ХНУВС. У дослідженні приймали участь 46 курсантів двох академічних груп другого року навчання. Було створено експериментальну і контрольну групи. Експеримент тривав протягом четвертого семестру. Проведено 40 практичних занять.

Фізична підготовленість курсантів визначалась з використанням таких тестових вправ: біг 100 м; комплексна силова вправа (30 сек) - згинання, розгинання рук в 
упорі лежачи, 30 с - підйом тулубу з положення лежачи на спині); підтягування на поперечині; стрибок у довжину з місця; підйом тулубу з положення лежачи на спині ноги зігнути; спеціалізований комплексний тест (на 10 метровій частині татамі виконувались - перекид вперед, перекид назад; 5 ударів по мішку - 2 ногами, 3 руками; кидок - передня підніжка та затримання - загин руки за спину ривком) і біг 1000 м. Навчальні заняття курсантів контрольної групи проводились повністю за наявною навчальною програмою.

\section{Результати дослідження}

Експериментальна група (24 курсанта) наприкінці основної частини заняття протягом 8-10 хвилин виконувала комплекс з 11-12 вправ швидкісно-силової спрямованості та вправ тактики самозахисту коловим методом за програмою з кросфіту. Час переходу від вправи до вправи поступово скорочувався від 30 до 3-5 с. Комплекс включав наступні вправи: вистрибування вгору 3 положення полуприсіду; підйом тулубу і ніг з положення лежачи на спині; згинання та розгинання рук в упорі лежачи; використання 2 перекидів вперед, 2 назад; з положення випаду ногою вперед в стрибку зміна положення ніг; підтягування на поперечині; захист від ударів ногою та руками; підйом гирі (16 або 24 кг) двома руками до грудей; застрибування на гімнастичну лаву двома ногами; підйом тулубу з положення лежачи на спині ноги зігнуті; звільнення від захватів та обхватів; у висі на поперечині підйом ніг вгору. Час виконання вправ поступово збільшувався від 30 до 60 с.

Аналіз вихідних результатів тестування на початку дослідження показав, що різниця між показниками фізичної підготовленості курсантів експериментальної і контрольної груп не мали достовірної різниці (значення $\mathrm{t}$ - критерію Стьюдента коливалось від 0,31 до 1,29; P>0,05). Наприкінці дослідження у курсантів експериментальної групи показники фізичної підготовленості покращилась від 3,3\% до 25,1\% (в середньому на 10,78\%) (табл. 1).

Покращення результатів тестування в експериментальній групі курсантів підтверджується достовірністю змін ( $t=2,42-5,13 ; p<0,05-0,001)$, лише в бігу на 1000 метрів середньогрупові результати були недостовірними $(t=1,63 ; p>0,05)$. (табл. 1)

У курсантів контрольної групи показники тестових вправ наприкінці дослідження поліпшились від 1,5\% до 9,8\% в (в середньому на 4,18\%), але недостовірно (t=0,55-1,98; $p>0,05)$ (табл. 2).

Порівняльний аналіз показників фізичної підготовленості курсантів експериментальної і контрольної груп наприкінці дослідження свідчить, що експериментальна програма занять дозволила достовірно покращити результати в швидкісно-силових тестових вправах і в спеціалізованому тесті (значення $\mathrm{t}$ критерію коливається від 2,37 до 5,80; p<0,05-0,001). В бігових вправах зміни були значними, але недостовірними (100м.-t=0,47; $\mathrm{p}>0,05 ; 1000$ м.-t=1,30; $\mathrm{p}>0,05$ ) (табл. 3)

Порівняння коефіцієнтів варіацій (V) показує, що щільність результатів, відповідно однорідність показників тестових вправ наприкінці експерименту у курсантів експериментальної групи суттєво краще. Так, в експериментальній групі значення коефіцієнта варіації коливається від 2,2 до 8,8 (в середньому V=6,3\%), а в контрольній групі середній показник V= 10,57\%, що свідчить про велику варіативність показників фізичної підготовленості курсантів цієї групи.

Таблиця 1

Показники фізичної підготовленості курсантів експериментальної групи (n-24) до і наприкінці експерименту

\begin{tabular}{|c|c|c|c|c|c|}
\hline \multirow{2}{*}{ Тести } & $\begin{array}{c}\text { До } \\
\text { експерименту }\end{array}$ & $\begin{array}{c}\text { Після } \\
\text { експерименту }\end{array}$ & $\begin{array}{c}\text { Відсоток } \\
\text { покращення }\end{array}$ & \multicolumn{2}{|c|}{ Достовірність } \\
\cline { 2 - 6 } & $\mathrm{x} \pm \mathrm{m}$ & $\mathrm{x} \pm \mathrm{m}$ & $\%$ & $\mathrm{t}$ & $\mathrm{p}$ \\
\hline Біг 100 (с) & $14,61 \pm 0,15$ & $14,13 \pm 0,13$ & 3,3 & 2,42 & $<0,05$ \\
\hline $\begin{array}{c}\text { Комплексна } \\
\text { силова вправа } \\
\text { (разів за хв) }\end{array}$ & $55,41 \pm 1,34$ & $62,73 \pm 1,08$ & 13,2 & 4,66 & $<0,05$ \\
\hline $\begin{array}{c}\text { Підтягування } \\
\text { (разів) }\end{array}$ & $12,26 \pm 0,54$ & $15,34 \pm 0,27$ & 25,1 & 5,13 & $<0,05$ \\
\hline $\begin{array}{c}\text { Стрибок в } \\
\text { довжину з місця } \\
\text { (см) }\end{array}$ & $234,41 \pm 1,63$ & $248,73 \pm 1,13$ & 6,1 & 7,26 & $<0,05$ \\
\hline $\begin{array}{c}\text { Підйом тулуба } \\
\text { (разів за хв.) }\end{array}$ & $49,13 \pm 1,26$ & $54,38 \pm 0,81$ & 10,7 & 3,5 & $<0,05$ \\
\hline $\begin{array}{c}\text { Спеціалізований } \\
\text { тест (с) }\end{array}$ & $13,4 \pm 0,51$ & $11,59 \pm 0,21$ & 13,7 & 3,36 & $<0,05$ \\
\hline Біг 1000 м (с) & $243,61 \pm 4,39$ & $235,29 \pm 2,62$ & 3,5 & 1,63 & $<0,05$ \\
\hline
\end{tabular}


Таблиця 2

Показники фізичної підготовленості курсантів контрольної групи (n-22) до і наприкінці дослідження

\begin{tabular}{|c|c|c|c|c|c|}
\hline \multirow{2}{*}{ Тести } & $\begin{array}{c}\text { До } \\
\text { експерименту }\end{array}$ & $\begin{array}{c}\text { Після } \\
\text { експерименту }\end{array}$ & \multicolumn{2}{|c|}{$\begin{array}{c}\text { Відсоток } \\
\text { покращення }\end{array}$} & \multicolumn{2}{|c|}{ Достовірність } \\
\cline { 2 - 6 } & $\mathrm{x} \pm \mathrm{m}$ & $\mathrm{x} \pm \mathrm{m}$ & $\%$ & $\mathrm{t}$ & $\mathrm{p}$ \\
\hline Біг 100(с.) & $14,48 \pm 0,16$ & $14,27 \pm 0,27$ & 1,5 & 0,67 & $>0,05$ \\
\hline $\begin{array}{c}\text { Комплексна силова } \\
\text { вправа (разів за хв.) }\end{array}$ & $54,69 \pm 1,12$ & $58,36 \pm 1,29$ & 6,7 & 1,98 & $>0,05$ \\
\hline $\begin{array}{c}\text { Підтягування } \\
\text { (разів) }\end{array}$ & $12,45 \pm 0,48$ & $13,68 \pm 0,64$ & 9,8 & 1,53 & $>0,05$ \\
\hline $\begin{array}{c}\text { Стрибок в довжину } \\
\text { з місця (см.) }\end{array}$ & $233,71 \pm 1,96$ & $236,49 \pm 1,78$ & 1,18 & 1,05 & $>0,05$ \\
\hline $\begin{array}{c}\text { Підйом тулуба } \\
\text { (разів за хв.) }\end{array}$ & $48,64 \pm 1,11$ & $50,86 \pm 0,93$ & 4,5 & 1,54 & $>0,05$ \\
\hline $\begin{array}{c}\text { Спеціалізований } \\
\text { тест (с.) }\end{array}$ & $13,18 \pm 0,43$ & $12,64 \pm 0,39$ & 4,1 & 0,95 & $>0,05$ \\
\hline Біг 1000 м (с.) & $245,48 \pm 4,41$ & $241,69 \pm 3,18$ & 1,5 & 0,55 & $>0,05$ \\
\hline
\end{tabular}

Таблиця 3

Показники фізичної підготовленості курсантів контрольної і експериментальної групи наприкінці дослідження

\begin{tabular}{|c|c|c|c|c|c|c|}
\hline Тести & $\begin{array}{c}\text { Контрольна } \\
\text { група } \\
(\mathrm{n}-22)\end{array}$ & $\begin{array}{c}\text { Варіатив } \\
\text { ність } \\
(\mathrm{V})\end{array}$ & $\begin{array}{c}\text { Експеримента } \\
\text { льна група } \\
(\mathrm{n}-24)\end{array}$ & \multicolumn{2}{|c|}{$\begin{array}{c}\text { Варіатив } \\
\text { ність } \\
(\mathrm{V})\end{array}$} & \multicolumn{2}{|c|}{ Достовірність } \\
\cline { 2 - 7 } & $\mathrm{x} \pm \mathrm{m}$ & $\%$ & $\mathrm{x} \pm \mathrm{m}$ & $\%$ & $\mathrm{t}$ & $\mathrm{p}$ \\
\hline Біг 100 (с) & $14,27 \pm 0,27$ & 8,9 & $14,13 \pm 0,13$ & 4,5 & 0,47 & $>0,05$ \\
\hline $\begin{array}{c}\text { Комплексна силова } \\
\text { вправа (разів за хв) }\end{array}$ & $58,36 \pm 1,29$ & 10,4 & $62,73 \pm 1,08$ & 8,4 & 2,60 & $<0,05$ \\
\hline $\begin{array}{c}\text { Підтягування } \\
\text { (разів) }\end{array}$ & $13,68 \pm 0,64$ & 21,9 & $15,34 \pm 0,27$ & 8,6 & 2,51 & $<0,05$ \\
\hline $\begin{array}{c}\text { Стрибок в довжину } \\
\text { з місця (см) }\end{array}$ & $236,49 \pm 1,78$ & 3,5 & $248,73 \pm 1,13$ & 2,2 & 5,80 & $<0,05$ \\
\hline $\begin{array}{c}\text { Підйом тулуба } \\
\text { (разів за хв) }\end{array}$ & $50,86 \pm 0,93$ & 8,6 & $54,38 \pm 0,81$ & 6,2 & 2,86 & $<0,05$ \\
\hline $\begin{array}{c}\text { Спеціалізований } \\
\text { тест (с) }\end{array}$ & $12,64 \pm 0,39$ & 14,5 & $11,59 \pm 0,21$ & 8,8 & 2,37 & $<0,05$ \\
\hline Біг 1000 м (с) & $241,69 \pm 3,18$ & 6,2 & $235,29 \pm 2,62$ & 5,4 & 1,30 & $>0,05$ \\
\hline
\end{tabular}

\section{Висновки/ Дискусія}

Проблемі удосконалення методики фізичної підготовленості курсантів в останні роки приділяється значна увага та розглядається у значній кількості наукових досліджень [2; 3; 7] Ці праці спрямовані на вирішення окремих аспектів процесу фізичної підготовки. Враховуючи зазначені протиріччя між нормативно-законодавчими вимогами та рівнем фізичної підготовленості майбутніх офіцерів Національної поліції [2; 3; 4; 5], необхідно вести пошук найбільш ефективних засобів, методів та форм фізичної підготовки курсантів.

У зв'язку із цим проведене дослідження з викорис- тання комплексу швидкісно-силових вправ та вправ 3 тактики самозахисту за кросфітовською програмою дозволило достовірно покращити результати в бігу на 100 м (t=2,42; $\mathrm{p}<0,05)$, у комплексній силовій вправі $(t=4,66 ; p<0,01)$, підтягуванні $(t=5,13 ; p<0,001)$, підйому тулубу $(t=3,5 ; p<0,05)$ та у вправах з тактики самозахисту $(\mathrm{t}=3,36 ; \mathrm{p}<0,05)$. Тому з метою покращення витривалості необхідно в програму підготовки курсантів збільшити об'єм бігової підготовки.

Перспектива подальших досліджень полягає у визначені оптимальних засобів та методів швидкісносилової та бігової підготовки курсантів. 
Конфлікт інтересів. Автори заявляють, що відсутній конфлікт інтересів, який може сприйматись таким, що може завдати шкоди неупередженості статті. Джерела фінансування. Ця стаття не отримала фінансової підтримки від державної, громадської або комерційної організації.

\section{Список посилань}

1. Бондаренко В. В., Радзієвський Р. М., Кримець О. І. (2019), «Динаміка показників фізичної підготовленості працівників патрульної поліції на етапі професійного становлення», Науковий часопис Національного педагогічного університету імені М.П. Драгоманова. Серія 15. Науково-педагогічні проблеми фізичної культури (фізична культура і спорт). Випуск 8 (116). С. $28-37$.

2. Боровик М.О.(2019), Окремі аспекти моніторингу фізичних здібностей майбутніх офіцерів Національної поліції України. стан та перспективи розвитку педагогіки та психології в Україні та світі: матеріали Міжнародної науково-практичної конференції. Ч.2. Київ: ГО «Київська наукова організація педагогіки та психології», С. 10-13.

3. Горпініч О. О. (2010), Оптимізація навчально-службової діяльності курсантів ВНЗ системи МВС засобами фізичного виховання: автореф. дис. на здобуття ступеня кинд. н. з фіз. вих. і спорту. Харків, 21 с.

4. Колєсніков В. В., Забора А.В. (2020), «Підвищення рівня фізичної підготовленості курсантів закладів вищої освіти МВС України засобами функціонального багатоборства (кросфіт)», Підготовка поліцейських в умовах реформування системи МВС України: зб. наук. пр. / МВС України, Харків. нац. ун-т внутр. справ, Каф. тактичної та спец. -фіз. підгот. ф-ту №2. Харків: ХНУВС, 336 с.

5. Коломієць Ю. М., Пашаєв А. 3., Уварова О. Ю. (2018), «Удосконалення рівня фізичної підготовки курсантів ВНЗ МВС України шляхом проведення секційної роботи зі спортивних єдиноборств», Підготовка поліцейських в умовах реформування системи МВС України. Харків, С. 73-76.

6. Кушніренко Р. О. (2019), «Окремі аспекти фізичної підготовки курсантів у закладах вищої освіти МВС України», Підготовка поліцейських в умовах реформування системи МВС України. (м. Харків, 31 травня 2019 року), С. $252-255$.

7. Моргунов О. А., Ярещенко О. А. (2020), «Фізична підготовка курсантів закладів вищої освіти зі специфічними умовами навчання МВС України», Підготовка поліцейських в умовах реформування системи МВС України: зб. наук. пр. МВС України, ХНУВС, Кафедра тактичної та спеціальної фізичної підготовки ф-ту №2. Харків: ХНУВС, 336 с.

8. Про Національну поліцію : Закон України від 02 липня 2015 року станом на 01 січня 2019 року. Відомості Верховної Ради (BВР), 2015, № 40-41, ст. 379. URL: https://zakon.rada.gov.ua/laws/show/ 580-19

9. Савчук П., Шестерова Л. (2016), «Розвиток специфічних координаційних здібностей і вестибулярної стійкості в процесі фізичної підготовки курсантів Національної академії Національної гвардії України», Слобожанський науково-спортивний вісник, №6 (56), С. 105-109.

10. Селюков В. С., Кушніренко Р. О., Константинов Д. В. (2018), «Фізичне виховання як напрям підготовки поліцейських в Україні», Порівняльно-аналітичне право, № 4, С. 338-340.

11. Kyslenko D., BondarenkoV., Plisko V., Bosenko A., Danylchenko V., Kuzmichova-Kyslenko Ye., Tylchyk V., Donets I. (2019), «Dynamics of security specialists' physical condition during professional training», Journal of Physical Education and Sport. No. 19 (2). P. 1099-1103.

12. Plisko V., Doroshenko T., Prontenko K. (2018), «Informational indicators of functional capacities of the body for teaching cadets from higher military educational institutions power types of sports», Journal of Physical Education and Sport. No. 17 (2). P. $1050-1054$.

13. Prontenko K., Griban G., Prontenko V., Bezpaliy S., Bondarenko V., Andreychuk V., Tkachenko P. (2017), «Correlation Analysis of Indicators of Athletes' Readiness and their Competitive Results in Kettlebell Sport», Journal of Physical Education and Sport. No. 17 (4). P. 2123-2128.

Стаття надійшла до редакції: 19.05.2021 р.

Опубліковано: 23.06.2021 р.

Аннотация. Андрей Забора, Олег Камаев. Совершенствование методики физической подготовки курсантов $3 В 0$ со специфическими условиями обучения Мвд Украины. Цель: разработать и экспериментально обосновать усовершенствованную методику физической подготовки курсантов. Материал и методы: исследование проведено на учебно-спортивной базе ХНУВД. В исследовании приняли участие 46 курсантов двух академических групп второго года обучения. Были созданы экспериментальная (n-24) и контрольная (n-22) группы. Эксперимент продолжался в течение четвертого семестра. В работе использованы следующие методы исследования: анализ и обобщение научно-методической информации, педагогическое наблюдение, тестирование, педагогический эксперимент, методы математической статистики. Результаты: за счет использования экспериментальной методики, подбора средств и методики выполнения комплексных упражнений получен прирост показателей физической и специальной подготовленности курсантов. Выводы: разработана методика совершенствования физической подготовки обеспечила достоверное улучшение показателей физической подготовленности курсантов, способствует успешному овладению упражнениями тактики самозащиты.

Ключевые слова: курсанты, физическая подготовка, тестирование, физические качества, кроссфит.

Abstract. Andrii Zabora, Oleg Kamaev. Improvement of the methodology of physical training of cadets of the Western Military District with specific training conditions of the Ministry of Internal Affairs of Ukraine. Purpose: to develop and experimentally substantiate the improved methodology of physical training of cadets. Material and methods: the study was carried out at the educational and sports base of the KNUVD. The study involved 46 cadets from two academic groups of the second year of study. Experimental ( $n-24)$ and control (n-22) groups were created. The experiment continued throughout the fourth semester. The following research methods were used in the work: analysis and generalization of scientific and methodological information, pedagogical observation, testing, pedagogical experiment, methods of mathematical statistics. Results: due to the use of the experimental methodology, selection of means and methodology of complex exercises fulfillment, an increase in the indices of physical and special readiness of cadets was obtained. Conclusions: the methodology of physical fitness improvement was developed; it provided a reliable improvement of cadets' physical readiness indices, contributes to the successful mastering of self-defense tactics exercises.

Keywords: cadets, physical training, testing, physical qualities, crossfit. 


\section{СЛОБОЖАНСЬКИЙ НАУКОВО-СПОРТИВНИЙ ВІСНИК}

\section{References}

1. Bondarenko, V. V., Radziievskyi, R. M., Krymets, O. I. (2019), «Dynamics of indicators of physical fitness of patrol police officers at the stage of professional development», Naukovyi chasopys Natsionalnoho pedahohichnoho universytetu imeni M.P. Drahomanova. Seriia 15. Naukovo-pedahohichni problemy fizychnoi kultury (fizychna kultura i sport). Vypusk 8 (116). pp. 28-37. (in Ukr.)

2. Borovyk, M. O. (2019), Okremi aspekty monitorynhu fizychnykh zdibnostei maibutnikh ofitseriv Natsionalnoi politsii Ukrainy. stan ta perspektyvy rozvytku pedahohiky ta psykholohii v Ukraini ta sviti: materialy Mizhnarodnoi naukovo-praktychnoi konferentsii. Ch.2. Kyiv: $\mathrm{HO}$ «Kyivska naukova orhanizatsiia pedahohiky ta psykholohii», pp. 10-13. (in Ukr.)

3. Horpinich, O. O. (2010), Optymizatsiia navchalno-sluzhbovoi diialnosti kursantiv VNZ systemy MVS zasobamy fizychnoho vykhovannia: avtoref. dys. na zdobuttia stupenia kynd. n. z fiz. vykh. i sportu. Kharkiv, 21 p. (in Ukr.)

4. Koliesnikov, V. V., Zabora, A.V. (2020), «Increasing the level of physical fitness of cadets of higher education institutions of the Ministry of Internal Affairs of Ukraine by means of functional all-around (crossfit)», Pidhotovka politseiskykh v umovakh reformuvannia systemy MVS Ukrainy: zb. nauk. pr. / MVS Ukrainy, Kharkiv. nats. un-t vnutr. sprav, Kaf. taktychnoi ta spets. -fiz. pidhot. f-tu №2. Kharkiv: KhNUVS, 336 p. (in Ukr.)

5. Kolomiiets, Yu. M., Pashaiev, A. Z., Uvarova, O. Yu. (2018), «Improving the level of physical training of cadets of universities of the Ministry of Internal Affairs of Ukraine by conducting sectional work on martial arts», Pidhotovka politseiskykh v umovakh reformuvannia systemy MVS Ukrainy. Kharkiv, pp. 73-76. (in Ukr.)

6. Kushnirenko, R. O. (2019), "Some aspects of physical training of cadets in higher education institutions of the Ministry of Internal Affairs of Ukraine», Pidhotovka politseiskykh v umovakh reformuvannia systemy MVS Ukrainy. (m. Kharkiv, 31 travnia 2019 roku), pp. 252-255. (in Ukr.)

7. Morhunov, O. A., Yareshchenko, O. A. (2020), «Physical training of cadets of higher education institutions with specific training conditions of the Ministry of Internal Affairs of Ukraine», Pidhotovka politseiskykh v umovakh reformuvannia systemy MVS Ukrainy: zb. nauk. pr. MVS Ukrainy, KhNUVS, Kafedra taktychnoi ta spetsialnoi fizychnoi pidhotovky f-tu №2. Kharkiv: KhNUVS, 336 p. (in Ukr.)

8. Pro Natsionalnu politsiiu : Zakon Ukrainy vid 02 lypnia 2015 roku stanom na 01 sichnia 2019 roku. Vidomosti Verkhovnoi Rady (VVR), 2015, № 40-41, p. 379. URL: https://zakon.rada.gov.ua/laws/show/ 580-19 (in Ukr.)

9. Savchuk, P., Shesterova, L. (2016), «Development of specific coordination abilities and vestibular stability in the process of physical training of cadets of the National Academy of the National Guard of Ukraine», Slobozhanskyi naukovo-sportyvnyi visnyk, №6 (56), pp. 105-109. (in Ukr.)

10. Seliukov, V. S., Kushnirenko, R. O., Konstantynov, D. V. (2018), «Physical education as a direction of police training in Ukraine», Porivnialno-analitychne pravo, № 4, pp. 338-340. (in Ukr.)

11. Kyslenko D., BondarenkoV., Plisko V., Bosenko A., Danylchenko V., Kuzmichova-Kyslenko Ye., Tylchyk V., Donets I. (2019), «Dynamics of security specialists' physical condition during professional training", Journal of Physical Education and Sport. No. 19 (2). P. 1099-1103. (in Eng.)

12. Plisko V., Doroshenko T., Prontenko K. (2018), «Informational indicators of functional capacities of the body for teaching cadets from higher military educational institutions power types of sports», Journal of Physical Education and Sport. No. 17 (2). P. 1050-1054. (in Eng.)

13. Prontenko K., Griban G., Prontenko V., Bezpaliy S., Bondarenko V., Andreychuk V., Tkachenko P. (2017), «Correlation Analysis of Indicators of Athletes' Readiness and their Competitive Results in Kettlebell Sport», Journal of Physical Education and Sport. No. 17 (4). P. 2123-2128. (in Eng.)

Received: 19.05 .2021$.

Published: 23.06.2021.

\section{Відомості про авторів / Information about the Authors}

Забора Андрій Володимирович: к.фіз.вих., доцент; Харківський національний університет внутрішніх справ: пр. Льва Ландау, 27, м. Харків, Україна.

Забора Андрей Владимирович: к. физ.восп., доцент; Харьковский национальный университет внутренних дел: пр. Льва Ландау, 27, г. Харьков, Украина.

Andrii Zabora: Candidate of Sciences in Physical Education and Sports, Associate Professor; Kharkiv National University of Internal Affairs: 27 Lva Landau Ave., Kharkiv, Ukraine.

ORCID: https://orcid.org/0000-0003-4952-1598

E-mail: raandrej1967@gmail.com

Камаєв Олег Іванович: д.фіз.вих., професор; Харківська державна академія фізичної культури: вул. Клочковська, 99, м. Харків, 61058, Україна.

Камаев Олег Иванович: д.физ.восп., профессор; Харьковская государственная академия физической культуры: ул. Клочковская, 99, г. Харьков, 61058, Украина.

Oleg Kamaev: Doctor of Sciences (Physical Education and Sports), Professor; Kharkiv State Academy of Physical Culture: 61058 ,

Kharkiv, st. Klochkivska, 99, Ukraine.

ORCID: https://orcid.org/0000-0003-4358-888X

E-mail: kamaevoi45@gmail.com 